\title{
Diethyl (dipyridyl) nickel (II)
}

提案者 山本隆一, 山本明夫 (東京工業大学資源化学研究所)


256.7 130.1

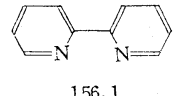
156.1

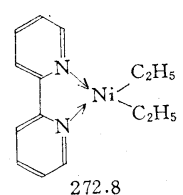

\section{I. 製 法 ${ }^{1)}$}

$250 \mathrm{ml}$ の三方コック付シュレンク型フラスコ（注意 1) にテフロンローター, bis(acetylacetonate)nickel (II) $10 \mathrm{~g}$ (0.039 mol) , 2,2'-dipyridyl $10 \mathrm{~g}(0.065 \mathrm{~mol})$ を入れ，すり合わせのセンをつけて真空ポンプで真空にした後，フラ スコ内に乾燥脱酸素”した窒素ガスを導入する。この操作を 3 度繰り返してフラスコ中を完全に空素置換した後に, 脱 水蒸留して窒素下に保存（注意 2 ）してあるジエチルエーテル $100 \mathrm{ml}$ を窒素気流中で注射器にとり, 窒素気流中で前 記シュレンク型フラスコに入れる。反応系を水で $0^{\circ} \mathrm{C}$ に泠やし,マグネチックスターラーでかくはんしながら, diethylaluminum monoethoxide $\mathrm{AlEt}_{2}(\mathrm{OEt}) 20 \mathrm{~m} l(0.13 \mathrm{~mol})$ （注意 3 ) を注射器にとり窒素ガス雰囲気下で徐々に滴下寸 る。このまま $0^{\circ} \mathrm{C} て ゙ ~ 1$ 時間かくはんした後反応系を室温 $\left(20^{\circ} \mathrm{C}\right)$ にもどす。室温でかくはんを続けると（注意 4 ) 約 3 時 間後にエーテル溶液が暗緑色に変わり，約10時間で反応が完結する。反応完結後静置して生成した diethyl (dipyridyl) nickel (II) を沈殿せしめた後, 窒素下で注射器を用いてエーテル層を注意深く除く。得られた残查中に残存する $2,2^{\prime}-$ dipyridyl およびアルミニウム化合物を除くために, 脱水蒸留して窒素下に保存してある $n$-ヘキサン $100 \mathrm{~m} l$ で十分に 洗う ( 2 回)。この後得られた濃暗緑色の錯体を脱水蒸留して窒素下に保存してあるベンゼン $100 \mathrm{~m} l$ に加熱溶解せしめ 窒素下で熱時口過する（注意 5 )。口液を室温にすると大きな結晶が析出する。この結晶を窒素下で口別し 真空乾燥す る。収量 $6.0 \sim 7.0 \mathrm{~g}$ (収率 $57 \sim 66 \%$ )。

\section{II. 注意事 項}

(1) すり合わせガラス器具を真空グリースを塗って用いる。1 $10^{-3} \mathrm{mmHg}$ で空気のもれがほとんどないものを用いる。

（2）すり合わせガラス器具の溶媒ビン（機能的にはシュレンク型フラスコと同じ役割をはたす）を窒素ガスで置換 し，この中に脱水脱酸素した溶媒を保存する。

(3) triethylaluminum $-30^{\circ} \mathrm{C}$ 以下でかくはんしながら等モルのエチルアルコールを加え, 生成した diethylaluminum monoethoxide を減圧下蒸留（100 $101^{\circ} \mathrm{C} / 7 \mathrm{mmHg} ）$ 精製したものをシュレンク型フラスコに窒素下で保存 する。

（4） 反応容器内が加圧になることがあるから，ときどき三方コックを瞬間的に開いて内部のガスを放出する。

（5） diethyl (dipyridyl) nickel（II）は沸とうベンゼン中で安定である。熱時口過の際にベンゼン溶液が泠却する のを防ぐには赤外線ランプを用いるとよい。

\section{III. 性質}

$\mathrm{mp} 97^{\circ} \mathrm{C}$ ぐらいから分解し始める(発生ガス: ブタンおよび少量のエタン, エチレン)。ジメチルホルムアミド, ア セトニトリル，ベンゼン，トルエン，テトラヒドロフランに易溶。エチルエーテルには少し溶ける。n-へキサンには難 溶。アセトンには易溶であるが，長時間（数日）放置すると diaceton alcohol および mesityl oxide の生成が認めら れる。八ロゲン化溶媒と汇反応する。空気 (酸素, 水蒸気), アルコール類 (発生ガス:エタン), 水 (発生ガス: エタ ン）に触れると分解する。IR $(\mathrm{KBr}): 2930$ 2 $2830,1595,1440,760 \mathrm{~cm}^{-1}$ 。可視スペクトル(テトラヒドロフラン): 410,690 $\mathrm{m} \mu$ 。 $\mathrm{NMR}$ ( $\tau$, ジメチルホルムアミド中) 8.84 (triplet $3 \mathrm{H}$ ), 9.18 (quartet $2 \mathrm{H}$ )。

\section{IV. 本法の利点}

一般にアルキル遷移金属錯体は不安定であるが，2２'-dipyridyl をニッケルに配位させることによって安定なエチル ニッケル錯体を単離することができた。またアルキル遷移金属化合物の合成には，グリニャール試薬やトリアルキルア ルミニウムを用いることが多いが，生成物が diethyl (dipyridyl) nickel（II）のように空気，水に対して不安定な場合 
にはグリニャール試薬を生成物から除くのは大変困難である。また，本法の 場 合トリアルキルアルミニウムは，2,2'dipyridyl および生成物と反応するので不適当である。

\section{引用文献}

1）山本明夫, 森藤和彦, 池田朔次, 斎藤太郎, 内田安三, 御園生晃, J. Am. Chem. Soc. 874652 (1965)： ibid. 901878 (1968)

2）日本化学会編「実験化学講座」 2 基礎技術II p. 66 丸善 (1956)

\section{5-Bromosalicylic acid}

提案者 浅岡忠知, 島崎長一郎, 宮島 晃

(富山大学工学部)

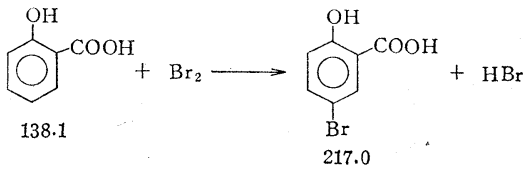

\section{I. 製法}

内容 $500 \mathrm{~m} l$ の四つロフラスコにかくはん機, 滴下漏斗, 温度計および還流冷却器を取り付け, 冷却器の上端は臭化 水素吸収装置（注意 1) にゴム管で接続しておく。四つロフラスコに salicylic acid $27.6 \mathrm{~g}(0.2 \mathrm{~mol})$, アンチモン粒 $4.0 \mathrm{~g}\left(0.003 \mathrm{~mol}\right.$ ) (注意 2 ) および四塩化炭素 $90 \mathrm{ml}$ (注意 3 ) を入れ, 温度を $70^{\circ} \mathrm{C}$ に保ち, かきまぜながら臭素 $32.0 \mathrm{~g}(0.2 \mathrm{~mol})$ を四塩化炭素 $50 \mathrm{~m} l$ に溶かした溶液を滴下漏斗から 3 時間かけて滴下寸る。加え終ってからさらに 同温で 3 時間かきまぜ続ける。放冷後, 反応混合物中の沈殿をこしわけ, $70 \sim 80^{\circ} \mathrm{C}$ (注意 4 ) の温水でよく洗浄し, 乾 燥する。このものをメタノール $200 \mathrm{~m} l$ に溶解し,アンチモン粒などを除去するため再度口過し, 口液に 70 100 $\mathrm{m} l$ の水 を加え, 室温で 1 時間内外静置した後, 生じた沈殿を吸引口過し, さらにメタノール-水系溶媒で $2 \sim 3$ 回再結晶精製す

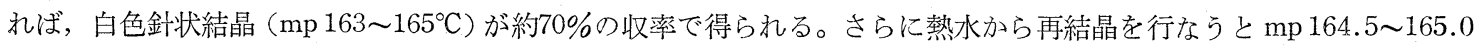
${ }^{\circ} \mathrm{C}$ の純品が約 $50 \%$ の収率で得られる。

\section{II. 注 意 事 項}

（1） 系化水素吸収装置内の吸収液は $10 \%$ 水酸化ナトリウム水溶液 $100 \mathrm{ml}$ で十分である。

（2）鉄粉が通常使用されるが，アンチモン粒 (20 mesh 以下) の方が約 $10 \%$ 収率が増大寸る。その他, 鉄粉は $5 \mathrm{~A}$ （東洋口紙）の定性口紙による吸引口過では 1 回の操作のみでは完全に除去できなく，また反応生成物は紫色に着色さ れるので製品がよごれる。

（3）四塩化炭素以外の溶媒としては，二硫化炭素 ${ }^{13}$ は応温度 $50^{\circ} \mathrm{C}$ で収率はやや多いが，引火性を考えれば有利 ではない。ベンゼンでは bromobenzene が副生し, 酢酸 ${ }^{2}$ では 3,5-dibromosalicylic acid が副生し, 溶媒としては不 適当である。

（4）洗浄温水の温度が $80^{\circ} \mathrm{C}$ 以上になると bromosalicylic acid の溶解損失がある。

\section{III. 性質}

$\mathrm{mp} \mathrm{164} 165^{\circ} \mathrm{C}$ の白色針状結晶（水から）。泠水には難溶であるが，熱水に溶ける。メタノール，エタノール，アセ トン，エーテルには易溶，クロロホルム，ベンゼンには室温では難溶であるが熱時には可溶。

\section{IV. 本法の利点}

5-bromosalicylic acid の製法としては dipotassium salicylate と次亜臭素酸カリウムとの反応 ${ }^{3,4)}$ のらな方法もあ るが，原料および操作の面からいって salicylic acid の臭素化法がもっとも実用的である。

ここに記した臭素化の条件は Heinzerling ${ }^{1}$ の報告をもとにして著者らが条件をしゅじゅ検討した結果，もっともよ かった条件を記載したものである。

\section{文献}

1) H. Heinzerling, Z. Chem. 710 (1871)

2) H.K. Silk, J. Chem. Soc. 261228 (1904) 